\title{
A Macroscopic Study of the Cross Section of Femur
}

\author{
By \\ Jang-Kuei Wei and Toshio Suzuki \\ Department of Anatomy, Keio University School \\ of Medicine, Tokyo, Japan \\ -Received for Publication, August 3, 1972-
}

\section{Introduction}

Bone formation and resorption occur continuously throughout life. In the long bone, the loss of bone tissue is seen progressively by endosteal resorption, while the deposition of new bone takes place at the periosteal surface. These two processes have opposite effects of the thickness of the cortical bone (Weimann 1955, Sedlin 1963, Smith 1964). Excessive focal resorption at the endosteal surfaces is a characteristic of aging and is responsible for the development of the postmenopausal and senile osteoporosis. The resorption cavities which are formed at the endosteal surface are three to four times larger in diameter than is a normal Haversian canal. These cavities can not be filled by new bone formation, presumably due to the restriction of the thickness of the Haversian wall to 125 microns which is considered to be maximal distance in providing the included osteons with nutrition by diffusion. This leaves a large central cavity unfilled, once they are formed. Macroscopically, the resorption spaces appear in the inner cortex as irregular holes, and increase in size through endosteal resorption to produce the characteristic appearance of senile osteoporosis.

The endosteal development of porosity induced by large sized resorption spaces has been noted and discussed by many investigators. However, none of them have pointed out what causes the excessively large resorption spaces and how they are regulated, although they are thought to be aligned with respect to physical loads on the skeleton by weight, muscle pull and function (Evans 1957, Frost 1963).

The purpose of this study is to investigate the distribution of resorption cavities in cross sections of the femur in human as a function 'of age. Their correlation to the disease status is also analyzed. 


\section{Materials and Methods}

Specimens were taken from mid-diaphysis of femur removed at autopsy. The subjects range from 22 to 93 years of age and include 48 males and 52 females. Children and patients with known metabolic bone diseases or loeal bone lesions (such as fracture, paget's disease, or skeletal metastase) were excluded from the study.

Cross sections of 1 to $1.2 \mathrm{~mm}$ in thickness were cut with a Bronwill diamond saw. The sections so prepared were too thick for reasonable resolution of osteons in the microradiograms but were excellent to define the size and pattern of distribution of cavities, and were sufficiently thick to preserve the delicate trabeculae which would have been lost in the preparation of ground bone sections.

The specimens were placed on the plate covered by high resolution emulsion, and exposed to the soft $x$-ray beam which is produced by an $x$-ray apparatus with a small-focus, industrial $x$-ray tube. The $x$-ray tube is operated at 20 kilovolts and the focal spot on the target is around 1.0 milimeter wide and about a centimeter long. The distance between the target and specimen is $50 \mathrm{~cm}$. The x-ray films were observed with a magnifier and pictures 5 times actual size were also made.

\section{Observation and Results}

On the basis of number and distribution of resorption spaces, the specimens were classified into six types (Fig. 1 to Fig. 6) as described below.

Type I (Fig. 1)

The endosteal surface is relatively smooth. Few large resorption spaces are found in the inner third (Fig. 7) of the cortical area. They are mostly located in the anterior and/or posterior quadrant. The cortex is relatively thick and the ratio of cortical to total cross section area is larger in comparison with that of the bone marrow cavity.

Type II (Fig. 2)

In this type, the number of resorption spaces is greater than in Type I, but they still stay in the inner third of the cortical area. None of them are found in the middle and outer third.

Type III (Fig. 3)

Marked subendosteal porosity extending to the middle third of the cortical thickness. Resorption cavities are found in both inner and middle thirds of the cortical area. They are usually located in the anterior and posterior quadrants, but they may spread in all 
four quadrants. Some cases show overy thin cortex but the cortical thickness is not always related to the number and distribution of resorption spaces.

Type IV (Fig. 4)

The involution of the cortex is most remarkable and porotic appearance of the bone is most distinct. The resorption spaces are found in all cortical areas......inner, middle and even in the outer third of the cortex. However, their sizes is largest in the endosteal zone and diminishes centrifiugally toward the periosteal surface.

Type V (Fig. 5)

The resorption spaces are scattered randomly throughout the area and thickness of the cortex. This type can be easily distinguished from the other types by the existence of isolated large resorption spaces in the middle and outer thirds of the cortical area.

Type VI (Fig. 6)

This type is characterized by many relatively small resorption spaces. They are uniform in size and are scattered diffusely throughout the full thickness of the cortex. In contrast to Type IV and V, few large resorption spaces appear in the middle or outer third of the cortical area. Resorption in the endosteal surface is not remarkable, although some large spaces may be found in the inner third of the cortical area.

The data of the study are tabulated (Table 1 through 6).

Type I through Type IV are arranged in increasing order of the number of resorption spaces arising near the endosteal surface and extending peripherally toward the periosteum.

The frequencies of six types in each decade are shown in Table 1 which indicates that the percentage of Type $I$ is higher in younger generations and decreases with increasing age. (This is the characteristic appearance of cortical bone encountered in healthy young adults dying acutely). The age related change in frequency of Type II reveals a tendency similar to Type I. The percentage is higher in the younger generations with the maximum in the 4 th decade and decreases with advancing age.

In contrast to Type I and Type II, which occur more frequently in young adults, Type III and IV are mostly found in the elderly. These facts indicate that cortical porosity increases in frequency and degree as a function of age. They also reveal that cortical resorption starts at the endosteal surface and progresses toward periosteal surface with increasing age.

As far as the first four types (Type I through Type IV) are concerned, the disease status of the individual seems to have less 
Table 1. Frequency vernus Age.

\begin{tabular}{|c|c|c|c|c|c|c|c|c|c|}
\hline & $20 / \mathrm{s}$ & $30 / \mathrm{s}$ & $40^{\prime} \mathrm{s}$ & $50 \mathrm{~s}$ & 60 's & $70^{\prime} \mathrm{s}$ & $80 / \mathrm{s}$ & $90^{\prime} \mathrm{s}$ & Total \\
\hline I & $50 . \stackrel{1}{0} \%$ & 57. $\stackrel{4}{1 \%}$ & $11.1 \%$ & $10.0 \%$ & $10.1 \%$ & 0 & 0 & 0 & 12 \\
\hline II & $50.0 \%$ & $28.6 \%$ & $55.6 \%$ & $\begin{array}{c}8 \\
40.0 \%\end{array}$ & $21.2 \%$ & $\begin{array}{c}2 \\
14.3 \%\end{array}$ & 0 & 0 & 25 \\
\hline III & 0 & 14. $\frac{1}{3} \%$ & 22. $2 \%$ & 35. ${ }^{7}$ & $\begin{array}{c}17 \\
51.5 \%\end{array}$ & $\begin{array}{c}8 \\
57.6 \%\end{array}$ & $73.6 \%$ & $50.0 \%$ & 44 \\
\hline IV & 0 & 0 & 0 & $5.0 \%$ & 0 & 14. $3 \%$ & 27. $2 \%$ & $50.0 \%$ & 8 \\
\hline V & 0 & 0 & 0 & $10.0 \%$ & $3.0 \%$ & 7. $1 \%$ & $9.2 \%$ & 0 & $\begin{array}{l}5 \\
\vdots\end{array}$ \\
\hline IV & 0 & 0 & $11.1 \%$ & 0 & $10.2 \%$ & 7. $1 \%$ & 0 & 0 & 6 \\
\hline Total & 2 & 7 & 9 & 20 & 33 & 14 & 11 & 4 & 100 \\
\hline
\end{tabular}

The data of the study are tabulated by age decade. The percent frequency, derived by dividing the number of cases in each type by the total number of cases in each decade, is also listed.

Table 2. Frequency versus Age-Acute Disease.

\begin{tabular}{|c|c|c|c|c|c|c|c|c|c|}
\hline & $20^{\prime} \mathrm{s}$ & $30^{\prime} \mathrm{s}$ & $40^{\prime} \mathrm{s}$ & $50^{\prime} \mathrm{s}$ & $60^{\prime} 8$ & $70^{\prime} \mathrm{s}$ & $80^{\prime} \mathrm{s}$ & $90^{\prime} \mathrm{s}$ & Total \\
\hline I & \multirow{6}{*}{1} & \multirow{6}{*}{$\begin{array}{l}1 \\
1\end{array}$} & & \multirow{6}{*}{1} & \multirow{6}{*}{$\begin{array}{l}1 \\
4\end{array}$} & \multirow{6}{*}{$\begin{array}{l}1 \\
2\end{array}$} & \multirow{6}{*}{$\begin{array}{l}1 \\
1\end{array}$} & \multirow{6}{*}{1} & 1 \\
\hline II & & & 2 & & & & & & 7 \\
\hline III & & & 1 & & & & & & 9 \\
\hline IV & & & & & & & & & 1 \\
\hline $\mathrm{V}$ & & & & & & & & & 0. \\
\hline VI & & & & & & & & & 0 \\
\hline Total & 1 & 2 & 3 & 1 & 5 & 3 & 2 & 1 & 18 \\
\hline
\end{tabular}

Table 3. Frequency versus Age-Chronic Disease

\begin{tabular}{|r|c|c|c|c|c|c|c|c|c|}
\hline & $20^{\prime} \mathrm{s}$ & $30^{\prime} \mathrm{s}$ & $40^{\prime} \mathrm{s}$ & $50^{\prime} \mathrm{s}$ & $60^{\prime} \mathrm{s}$ & $70^{\prime} \mathrm{s}$ & $80^{\prime} \mathrm{s}$ & $90^{\prime} \mathrm{s}$ & Total \\
\hline I & 1 & 3 & 1 & 2 & 4 & & & & 11 \\
II & & 1 & 3 & 7 & 6 & 1 & & 0 & 18 \\
III & & 1 & 1 & 7 & 13 & 6 & 6 & 1 & 35 \\
IV & & & & 1 & & 2 & 2 & 2 & 7 \\
V & & & & 2 & 1 & 1 & 1 & & 5 \\
VI & & & 1 & & 4 & 1 & & & 6 \\
\hline Total & 1 & 5 & 6 & 19 & 28 & 11 & 9 & 3 & 82 \\
\hline
\end{tabular}

effect on the type of resorption than does the age (Table I and III).

All eleven individuals who show Type V and VI, died of chronic diseases (Table V). Among them, four had hyperthyroidism (two 
Table 4. Frequency as Related to Acute Disease.

\begin{tabular}{|c|c|c|c|c|c|c|c|}
\hline & $\underset{\text { Accident }}{\mathrm{A}}$ & $\begin{array}{c}\text { B } \\
\text { Acute } \\
\text { Bleeding }\end{array}$ & $\begin{array}{c}\text { C } \\
\text { Cerebral } \\
\text { Disease }\end{array}$ & $\begin{array}{c}\mathrm{D} \\
\text { Pulmonary } \\
\text { Disease }\end{array}$ & $\begin{array}{c}\mathbf{E} \\
\text { Cardio- } \\
\text { Vascular } \\
\text { Disease }\end{array}$ & $\begin{array}{c}\text { F } \\
\text { Misc. }\end{array}$ & Total \\
\hline I & 1 & & & & & & 1 \\
\hline II & 2 & 1 & 2 & 1 & & 1 & 7. \\
\hline III & 1 & 1 & 3 & 1 & 2 & 1 & 9 \\
\hline IV & & & & 1 & & & 1 \\
\hline $\mathrm{V}$ & & & & & & & 0 \\
\hline VI & & & & & & & 0 \\
\hline Total & 4 & 2 & 5 & 3 & 2 & 2 & 18 \\
\hline
\end{tabular}

Table 5. Frequency as Related to Chronic Disease

\begin{tabular}{|r|c|c|c|c|c|c|c|c|}
\hline & $\begin{array}{c}\text { A } \\
\text { Cancer }\end{array}$ & $\begin{array}{c}\text { Cardio- } \\
\text { Vascular } \\
\text { Disease }\end{array}$ & $\begin{array}{c}\text { Cerebral } \\
\text { Disease }\end{array}$ & $\begin{array}{c}\text { D } \\
\text { Renal } \\
\text { Disease }\end{array}$ & $\begin{array}{c}\mathrm{E} \\
\text { Cirhosis } \\
\text { of } \\
\text { Liver }\end{array}$ & $\begin{array}{c}\mathbf{F} \\
\text { Gastric } \\
\text { Ulcer }\end{array}$ & $\begin{array}{c}\text { G } \\
\text { Endo- } \\
\text { crine } \\
\text { Disease }\end{array}$ & $\begin{array}{c}\mathbf{H} \\
\text { Misc. }\end{array}$ \\
\hline I & 3 & 3 & & 1 & 2 & 1 & & 1 \\
II & 8 & 3 & 2 & 2 & 1 & 1 & & 1 \\
III & 12 & 9 & 1 & 4 & 3 & 1 & 2 & 2 \\
IV & 2 & 2 & 1 & 1 & 1 & & & 1 \\
V & 1 & 1 & & & & 1 & 2 & \\
IV & 1 & 1 & & 1 & & 1 & 2 & \\
\hline
\end{tabular}

Table 6. Lacation of Resorption Cavities

\begin{tabular}{|r|c|c|c|c|c|}
\hline & Ant. Quad. & Post. Quad. & Med. Quad. & Lat. Quad. & No. of Cases \\
\hline I & 10 & 9 & 5 & 3 & 12 \\
II & 19 & 21 & 15 & 16 & 25 \\
III & 39 & 41 & 26 & 20 & 44 \\
IV & 8 & 8 & 8 & 8 & 8 \\
V & 5 & 5 & 5 & 5 & 5 \\
VI & 6 & 6 & 6 & 6 & 6 \\
\hline Total & 87 & 90 & 65 & 58 & 100 \\
\hline
\end{tabular}

with diffuse hyperplastic geiter and one with a toxic follicular adenoma). Therefore Type V and VI can be considered as pathological states.

When the cortical area of the femoral cross section is divided into four quadrants (Fig. 8), there are preferential sites of resorption in the formation of large cavities, regardless of age and type of case. Resorption spaces tend to be more numerous and larger in size in the anterior ad/or posterior quadrants, than in the medial 
and/or lateral quadrants (Table VI). Since anterior and posterior surfaces have more muscular attachment than medial and lateral surfaces, the formation of the large cavities must be related with muscular attachment and tensile function.

\section{Discussion}

Despite many controversial aspects of bone resorption, it can not be doubted that there are some factors which evoke and control osteoblastic activity, generally throughout the organism, or locally in the circumscribed area of bone (Weimann 1955, Jaffe 1930, Mclean 1966).

The presented observational data suggests that three types of mechanism for regulating the remodeling of secondary (adult type) bone should be considered. The first one is of systematically acting factors which regulate overall bone metabolism through body ${ }^{7}$ fluid levels of various hormones from glands such as the parathyroid, adrenal, ovary. Secondly, there are mechanical stresses directly applied to the skeletal elements. Lastly, local factors such as vascularity, various cell populations, otc., that modify or induce various responses on a local basis must be considered.

Albright (1940) suggested that the decrease of anabolic hormone in old age is the cause of osteoporosis. In this study the increase of resorption cavities as a function of age can be considered as a part of osteoporotic change of bone in general, although the site and progression of the resorption cavities are chiefly affected by some mechanical and functional factors.

The systematic or general factors due to hyperfunction of endocrine glands could increase the overall activity of the resorption process and promote resorption diffusely as seen in hyperparathyroidism or hyperthyroidism (Type VI, Fig. 6). However, the resorption cavities occur locally (endosteally) and focally at specific sites in all cases (except Type VI), this suggests that factors other than aging are operative in determining their progression.

It is generally agreed that change of hormonal situation in aging results in decrease of bone mass. When this occurs, internal architecture must be changed in a way that best withstands mechanical and functional stresses. Allison and Brooks (1921) noted that as a result of disease the earliest changes in bone occurred in the cancellous portion, which is considered less significant for weight-bearing or withstanding mechanical stress (Wollf 1870, Tobin 1955). Siffert (1967) also has observed a similar resorption process in his experiment with trabecular bone. For the same reason, the endosteal 
portion of the cortex is less important than the periosteal side. Therefore, the former is first resorbed in porotic change of the bone.

Thus the aging change of the cortical bone is assumed to occur primarily in the endosteal surface and resorption spaces spread progressively toward the periosteal surface without changing the external form of the bone.

Type V and VI show a peculiar feature of bone resorption which should be regarded as a pathologic state.

The scattered, large resorption spaces found distinctly in the middle and outer thirds of the cortical area in two carcinoma cases have impressed us that selected areas may be affected by the change of the local vascular supply caused by carcinoma.

\section{References}

Albright, F., Bloomberg, E. and Smith, P.H. Postmenopausal osteoporosis. Tr. A. Am. Phys., $55: 298,1940$.

Allison, N. and Brooks, B. Bone atrophy. An experimental study of the changes in bone which results from non-use. Surg. Gynec. and Obst., 33 : 250-260, 1921.

Evans, F.G. Stress and strain in bones. Springfield, III. : Charles C. Thomas, 1963.

Frost, H.M. Bone Remodeling Dynamics. Springfield, III. : Charles C. Thomas, 1963.

Jaffe, H.L. The absorption of Bone. Arch. Surg. $20: 355,1930$.

Mclean, F.C. and Urist, M.R. Bone: An introduction to the physiology of skeletal tissue. Chicago: Univ. of Chicago Press, 1966.

Sedlin, E., Frost, H.M. and Villanueva, A.R. Variations in Cross Section area of rib. cortex with age. J. Geront. 18 : 9-13, 1963.

Siffert, R.S. Trabecular patterns in bone. Amer. J. Roentgen. 99: 746-755, 1967.

Smith, R.W. and Walker, R.R. Femoral expansion in aging women. Implications for osteoporosis and fractures. Science. $145: 156-157,1964$.

Tobin, W.J. The internal architecture of the femur and its clinical significance. J. Bone and Joint Surg. 37A : 57-88, 1955.

Weimann, J.P. and Sicher, H. Bone and bones. St. Louis, Mo. C.V. Mosby Co., 2nd ed., 1955.

Wolff, J. Über die innere Architektur der Knochen und ihre Bedeutung für die Frage von Knochenwachstum. Virchow's Arch. $50: 389-450,1870$. 
Plate I
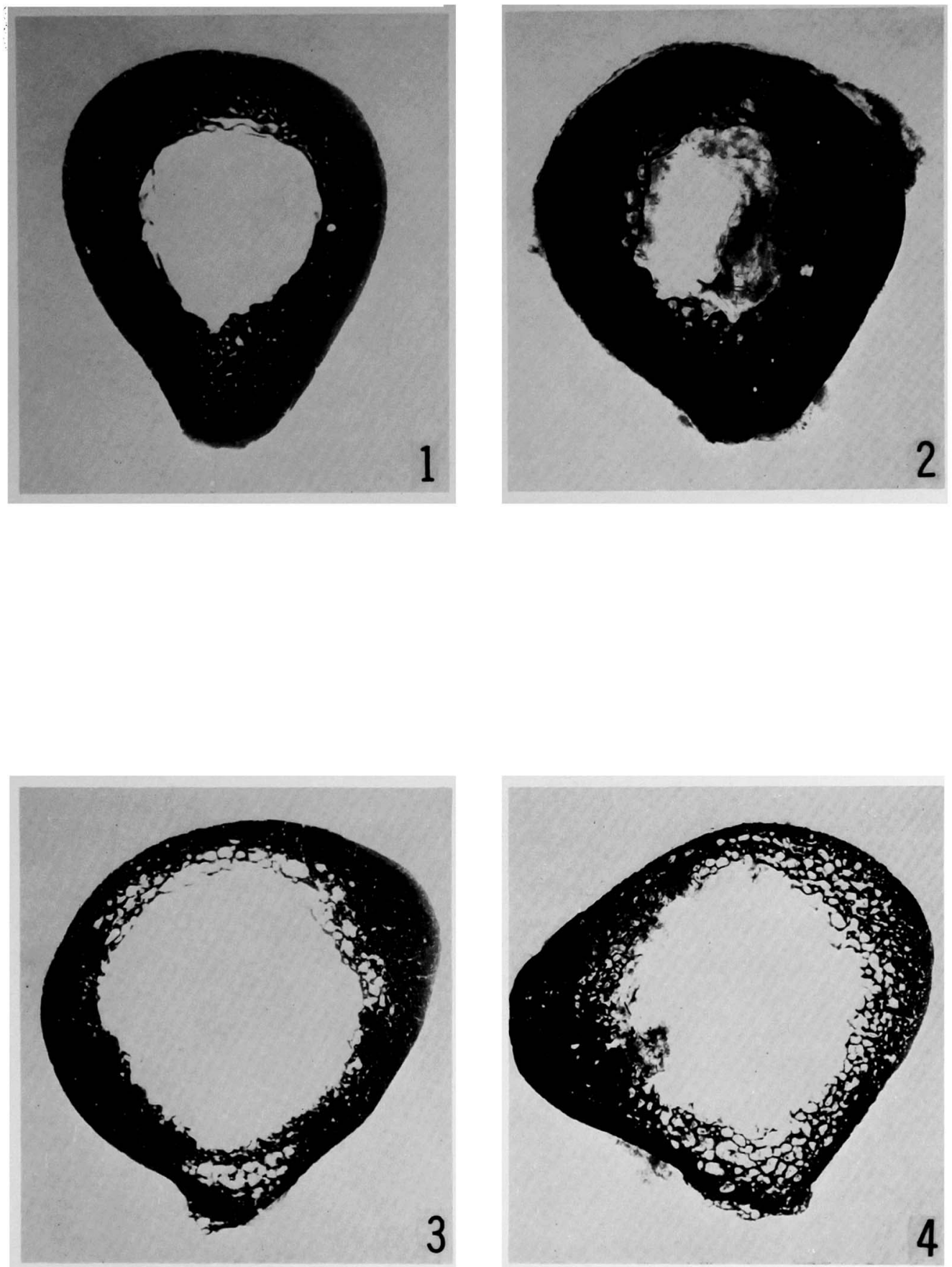

J.-K. Wei and T. Suzuki 
Plate II
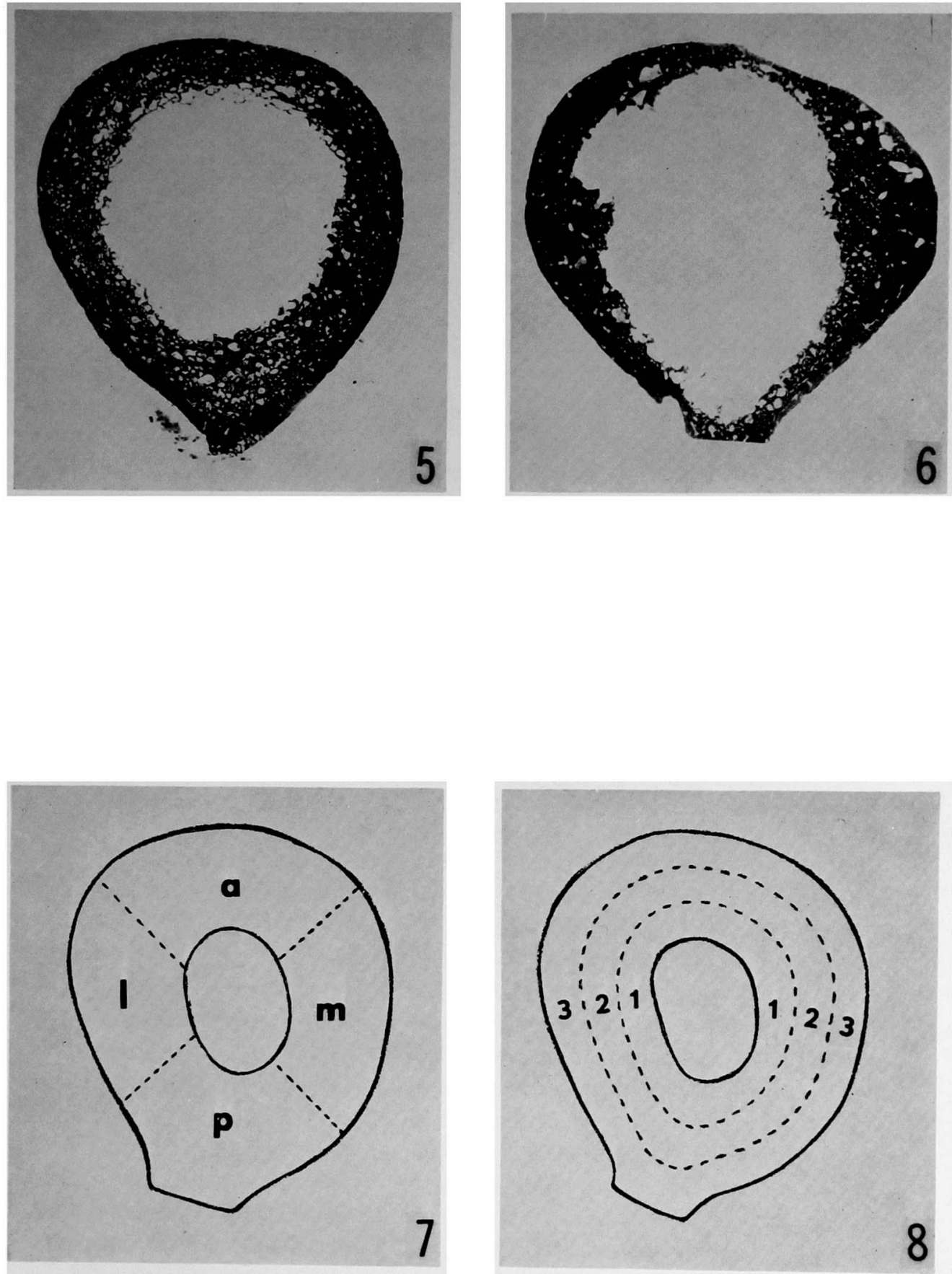

J.-K. Wei and T. Suzuki 